\title{
RELATIONSHIP BETWEEN ANTIOXIDANT PROPERTIES AND NUTRITIONAL COMPOSITION OF SOME GALACTOPOIETICS HERBS USED IN INDONESIA: A COMPARATIVE STUDY
}

\author{
ADE CHANDRA IWANSYAH ${ }^{\mathrm{a}, \mathrm{b}}$, RIZAL M DAMANIKc, LILIK KUSTIYAHc, MUHAMMAD HANAFI \\ aCenter for Appropriate Technology Development, Indonesian Institute of Sciences, Subang 41213, West Java, Indonesia, bPostgraduate \\ Student, Department of Community Nutrition, Faculty of Human Ecology, Bogor Agricultural University, Indonesia, cDepartment of \\ Community Nutrition, Faculty of Human Ecology, Bogor Agricultural University, Bogor, Indonesia, ${ }^{\mathrm{d}}$ Research Center for Chemistry, \\ Indonesian Institute of Sciences, PUSPIPTEK, Indonesia \\ Email: chandra.iwansyah@gmail.com,damanik@ipb.ac.id
}

Received: 31 Aug 2016 Revised and Accepted: 18 0ct 2016

\begin{abstract}
Objective: The objectives of this research were to evaluate and compare the antioxidant activity; phenolics and flavonoids contents; and chemical composition of some galactopoietic herbs used in Indonesia and to find a possible relationship between antioxidant activity; phenolics, flavonoids and chemical composition of these plants.

Methods: A wide range of analytical parameters was studied, including yield; $\mathrm{pH}$; water activity ( $\left.\mathrm{a}_{\mathrm{w}}\right)$; total color difference; phenolics and flavonoids content; moisture; ash; protein; fat; carbohydrate; fiber; calcium; zinc; magnesium; potassium; iron content; and the data were analyzed by partial least squares (PLS) regression analysis and principal component analysis (PCA) to evaluate the correlation between the parameters and classification of the plants. Folin-cioceltaeu assay, aluminum chloride assay and DPPH scavenging assay were used to evaluate of total phenolics content and free radical scavenging activity of the ethanolic extract of galactopoietic herbs.

Results: All of the galactagogue herbs, viz. Plectranthus amboinicus (Lour.) (PA), Sauropus androgynus (SA), Moringa oleifera (M0), and Carica papaya leaves (CP) exhibited good results of TPC, TFC and antioxidant activity. MO contained the highest average of total phenolics content (53.89 $\mathrm{mg}$ GAE/g). SA with a ratio of total flavonoids to total phenolics (TF/TP) which is 1.59 contained the highest average of total flavonoids and antioxidant activity ( $\mathrm{IC}_{50}$ ), $43.63 \mathrm{mg} \mathrm{QE} / \mathrm{g}$ and $126.13 \mu \mathrm{g} / \mathrm{ml}$, respectively, followed by MO>CA $>$ PA. Based on PLS and PCA analysis, antioxidant activity correlated with fat, protein, phenolics content, flavonoids content and $\mathrm{pH}$, but only the total flavonoids content correlated strongly with antioxidant activity.
\end{abstract}

Conclusion: This provides useful data about the studied relationships and chemical patterns in some galactopoietic herbs used and provides a helpful tool for understanding much more about the interpretation of results from the experiments and the mechanism of biosynthesis in plants.

Keywords: Antioxidant activity, galactopoietic herbs, physicochemical composition, partial least square (PLS) regression, principal component analysis (PCA).

(C) 2016 The Authors. Published by Innovare Academic Sciences Pvt Ltd. This is an open access article under the CC BY license (http://creativecommons.org/licenses/by/4. 0/]

DOI: http://dx.doi.org/10.22159/ijpps.2016v8i12.14964

\section{INTRODUCTION}

During many centuries, several parts of edible plants have been used as medicines. They contain bioactive compounds, such as phenolic compounds. Plant phenolic compounds can reduce the deleterious effects of reactive oxygen species (ROS) on a number of biological and pathological processes [1]. Since it's important and beneficial to health, the search for antioxidant from natural sources has received much attention.

Indonesia has a culture in utilizing the natural resources of plants as a traditional medicine. Indigenous knowledge about the uses of plants has often been evolving for a long time through trial and error and still is passed from generation to generation by oral tradition.

Breast milk has long been accepted as the gold standard of infant nutrition. Fulfillment of the nutritional needs of infants 0-6 mo of absolute acquired through breast milk [2]. Mother's perception associated with inadequate milk production is the reason that reported by mothers during early lactation [3]. The uses of natural galactagogues are an alternative solution for these problems [4].

Galactogogues are substances thought to assist in the initiation, continuation, or augmentation of breast milk production [5]. Many traditional foods and herbs for postpartum women that are meant to increase the mother's strength and enhance lactation [6]. Local knowledge showed that the traditional medicinal plants in Indonesia that be known as facilitating breastfeeding are Plectranthus amboinicus (Lour.), Sauropus androgynous, Moringa oleifera and Carica papaya leaves and many others [7-10].
Plectranthus amboinicus (Lour.) (PA) belongs to family Lamiaceae reported has been used as a galactagogue by Bataknese people in Indonesia [8]. Proposed mechanism based on a mouse model, PA has an effect on the proliferation of mammary secretory cells and increase DNA and RNA level $[8,11,12]$. Meanwhile, Moringa oleifera leaves (MO), family Moringaceae, has been used by Madura people to increase milk production by giving to mothers after postpartum. According to [10] and [13], MO leaves can increase milk production through the possibility of estrogenic and steroidal action. The Sauropus androgynus leaves (SA) belonging to the family Phyllanthaceae have been known to increase the breast milk production since ancient time in Indonesia [7]. SA was richest of flavonoid compounds with mechanism estrogenic and steroidal action, which can stimulate and increase milk production $[7,14,15]$. The ethnobotanic research of medical plants showed that Carica papaya leaves (CP), family Caricaceae, is one of the uses plants by Lauje ethnic communities in Central Sulawesi, Indonesia [9]. The mechanism of CP to increase human breast milk has been unknown yet.

Some galactopoietic herbs have a good antioxidant capacity. The relationship between the phenolic compounds and antioxidant capacity have been reported by many literatures, but the relationship and their contribution to the antioxidant activity have not been clear [16]. However, to the best of our knowledge, the comparison and relationship between chemical composition and antioxidant capacity of galactopoietic herbs used in Indonesia was not clearly understood and remains scarce. Therefore, the aims of this research were to evaluate and compare the antioxidant activity, 
phenolics content, flavonoids contents, and chemical composition of some galactopoietics herbs used in Indonesia and to find a possible relationship between antioxidant activity, phenolics, flavonoids and chemical composition of these plants by using linear regression analysis (partial least square, PLS). Principal component analysis (PCA) was applied to the data obtained in order to separate the plants into homogenous groups.

\section{MATERIALS AND METHODS}

In this section, materials and methods of this study are discussed.

\section{Reagents and solvent}

Gallic acid, quercetin, folin-cioceltaeu's phenol reagent, and 1,1-diphenyl 2-picrylhydrazyl (DPPH) were purchased from Sigma-Aldrich (Missouri,
US). Sodium carbonate, sodium nitrite, aluminum chloride, ethyl acetate, n-hexane, ethanol and sodium hydroxide were purchased from Fisher Scientific. All the reagents were of analytical grade.

\section{Plant materials}

Fresh leaves Plectranthus amboinicus (Lour.) (PA), Moringa oleifera (MO), and Carica papaya leaves (CP) were collected from Sukabirus garden-Bogor, Indonesia, during the month of October 2015-March 2016; Sauropus androgynous (SA) was carried out from traditional market "Gunung batu", Bogor-Indonesia (table 1). Botanical identification was performed by Dr. J. S Rahajoe, Botanist from "Herbarium Bogoriense", Research Center for Biology, Indonesian Institute of Sciences (No. 145/IPH.1.01/II.8/II/2015), where the voucher specimen has been deposited.

Table 1: Herbs reported to have galactopoietic properties and were used in Indonesia

\begin{tabular}{|c|c|c|c|}
\hline Common name & $\begin{array}{l}\text { Botanical } \\
\text { name }\end{array}$ & $\begin{array}{l}\text { Parts } \\
\text { used }\end{array}$ & Chemical constituents \\
\hline $\begin{array}{l}\text { Torbangun, Bangun- } \\
\text { bangun (Bataknese, } \\
\text { North Sumatera); } \\
\text { Daun Jinten } \\
\text { (Sundanese, } \\
\text { Javanese) }\end{array}$ & $\begin{array}{l}\text { Plectranthus } \\
\text { amboinicus } \\
\text { (Lour.) or } \\
\text { Coleus } \\
\text { amboinicus L. }\end{array}$ & leaf & $\begin{array}{l}\text { Carvacrol, thymol, } \beta \text { - } \\
\text { caryophyllene, cholorogenic } \\
\text { acid, rosmarinic acid, } \\
\text { kaempferol, quercetin, rutin, } \\
\text { caffeic acid, myricetin, } \\
\text { luteolin, apigenin }\end{array}$ \\
\hline
\end{tabular}

Katuk (Sundanese), Sauropus leaf phytol, squalene, linolenic babing (Javanese), androgynous acid (C18:3 $1 \omega 3)$, palmitic acid simani (C16:0), linoleic acid

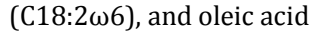

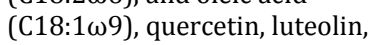
myricetin, luteolin, apigenin,

Kelor (Madura, Moringa oleifera leaf Sundanese), limaran (Javanese)

(Minangkabau)

Pepaya (Indonesia), $\quad$ Carica papaya leaf
gedang (sundanese).
glucosides, rutinosides malonyl glucosides, acetylglucosides of kaempferol, and isorhamnetin. kaempferol, caffeic acid, 5,7kaempferol, caffeic acid, 5 ,
dimethoxycoumarin, pcoumaric acid, protocatechuic acid

How to use
"bangun-bangun soup", the
leaves are crushed into
powder, then squeeze until
"langu" aroma is lost. Then,
cook the coconut milk,
vegetables, and chicken until
cooked. Enter torbangun
leaf shapes, salt, cook, and
stirring until tender of
leaves. Lift and add the lime
juice.

\begin{tabular}{ll}
$\begin{array}{l}\text { Proposed } \\
\text { mechanism }\end{array}$ & References \\
\hline $\begin{array}{l}\text { proliferation } \\
\text { of mammary } \\
\text { secretory cells }\end{array}$ & $8,12,17-20$ \\
\hline
\end{tabular}

"sayur bening", the leaves on the sprout are picked, washed, cooked in boiling water, flavored recipe vegetable nodes. Leaves and water are consumed as a side dish with rice. the leaves on the sprout are picked, washed, cooked in boiling water $(300 \mathrm{ml})$, adding "salam" leaves, onion, salt, and brown sugar. Then, left for $10 \mathrm{~min}$ and soup consumed as a side dish with rice.

possibly estrogenic steroidal action.

unknown, possibly estrogenic, steroidal action.
boiled or steamed, the leaves can be cooked with coconut "sambal" or takes 3 pieces of young leaves of papaya, squeeze, then heated until wilted. Then put it in the breast.

unknown
$7,15,21$
9, 25-27

\section{Extraction and fractionation of galactopoietics herbs}

The fresh leaves of PA ( $200 \mathrm{~g})$ were washed three times with tap water and then extracted with water or ethanol $96 \%$ for $24 \mathrm{~h}$. The supernatant was filtered through filter paper (Whatman No. l), and the resultant extract was dried by vacuum evaporator. The ethanolic extract (13.2 g) was dissolved in water and methanol, soaked for $12 \mathrm{~h}$, and filtered again, thus obtaining the crude extract. This crude extract was then partitioned with hexane $(300 \mathrm{ml}$ fractions repeatedly up to decolorization of the organic solvent), thus obtaining both the hexane fraction and the "clean" or "defatted" crude extract. The defatted, crude extract was then successively partitioned with ethyl acetate (EtOAc) (as for the hexane partition), thus obtaining the fraction of EtOAc, and aqueous fractions. Meanwhile for comparison, other galactopoietic herbs, viz. SA, MO and CP were extracted by the maceration method with ethanol for $24 \mathrm{~h}$.

\section{Physicochemical composition}

Nutritional composition was determined in accordance with [28], i.e., moisture content by direct heating (oven); ash by the muffle furnace; protein by semi-micro-kjeldahl nitrogen with a conversion factor of 6.25; lipids by soxhlet method; crude fiber by the gravimetric method; and carbohydrate by the luff schrool method. The energy was measured by direct application of Atwater factor $(1$ $\mathrm{g}$ carbohydrate $=4 \mathrm{kcal} ; 1 \mathrm{~g}$ fat $=9 \mathrm{kcal} ; 1 \mathrm{~g}$ protein $=4 \mathrm{kcal}$ ). Minerals (calcium, zinc, magnesium and iron) were determined by atomic absorption spectrometry methods. Meanwhile, physical properties, i.e. yields, $\mathrm{pH}$, water activity $\left(\mathrm{a}_{\mathrm{w}}\right)$ and total color difference were determined. The total color differences between all three coordinates were determined by colorimeter $3 \mathrm{nh}$. The color notation system is characterized by three values, which are $L$ (lightness), $a$ (redness), and $b$ (yellowness). 


\section{Total phenolics content}

The total phenolics content was determined using a modified folincioceltaeu assay [29]. The aliquot of sample $(0.1 \mathrm{ml})$ or blank or gallic acid standard solution $(0 ; 5 ; 10 ; 20 ; 30$ and $40 \mu \mathrm{g} / \mathrm{ml})$ were added distilled water $(2.8 \mathrm{ml})$ and sodium carbonate $(2 \%, 2 \mathrm{ml})$ and left standing for $4 \mathrm{~min}$. Then, $100 \mu \mathrm{l}$ folin-cioceltaeu was added, and the solutions were left standing for another $30 \mathrm{~min}$. The measurement was conducted on a spectrophotometer Agilent Technology Cary 60 UV-Vis $(\lambda=760 \mathrm{~nm})$ against a blank. Total phenolics content was derived using expressed as mg gallic acid equivalent (GAE) ing of dry weight of plant extract $\left(R^{2}: 0.99\right)$. Samples were analyzed in triplicates.

\section{Total flavonoids content}

Total flavonoids content was measured by aluminum chloride colorimetric assay with modification [30]. To the extract or fraction solution $(500 \mu \mathrm{l})$ or standard solution of quercetin $(0-200 \mu \mathrm{g} / \mathrm{ml})$ was added to separate $10 \mathrm{ml}$ volumetric flask containing $2 \mathrm{ml}$ of distilled water. Into the flask was added $150 \mu \mathrm{l}$ of $5 \% \mathrm{NaNO}_{2}$ solution and left to stand for five minutes. A solution of $10 \% \mathrm{AlCl}_{3}(150 \mu \mathrm{l})$ was added and left to stand for $6 \mathrm{~min}$. A solution of $1 \mathrm{M} \mathrm{NaOH}(2 \mathrm{ml})$ was added and the total volume diluted to $5 \mathrm{ml}$ with distilled water. Then, the solutions were mixed well. The measurement was conducted on a spectrophotometer Agilent Technology Cary 60 UV-Vis at $\lambda=510 \mathrm{~nm}$ against a blank. Total flavonoids content was expressed as mg quercetin equivalents $(\mathrm{QE})$ in dry weight of plant extract $\left(R^{2}: 0.99\right)$. Samples were analyzed in triplicates.

\section{Free scavenging activity (DPPH) assay}

The free radical scavenging activity of the extracts, based on the activity of the stable DPPH free radical, was determined by a method described by [20]. An accurately weighed sample of extracts or fraction of plant prepared by maceration extraction was placed in a volumetric flask and make up a stock concentration of $1000 \mu \mathrm{g} / \mathrm{ml}$. The curve for extracts was constructed using five different concentrations $(0 ; 10 ; 50 ; 100$; and $200 \mu \mathrm{g} / \mathrm{ml}$ ). To the extract solutions of different concentrations (each $1 \mathrm{ml}$ ) or blank or standard was added $3 \mathrm{ml}$ of $0.004 \%$ DPPH methanolic solution which was left standing in the dark for $30 \mathrm{~min}$. The measurement was conducted on a spectrophotometer Agilent Technology Cary 60 UV-Vis $(\lambda=515$ $\mathrm{nm}$ ) against a blank. The data were derived using expression and reported as the concentration of antioxidant required for $50 \%$ scavenging of DPPH radicals in a specified time period ( $\left.\mathrm{IC}_{50}\right)$. Next, $\mathrm{IC}_{50}$ was measured with quercetin as a standard. Antioxidant activity expressed as mg quercetin equivalent (QE) in dry weight of plant extract. Samples were analyzed in triplicates.

$$
\% \text { inhibition }=\left[\frac{(\mathrm{Ac}-\mathrm{As})}{\mathrm{Ac}}\right] \times 100
$$

Where: $A_{c}=$ absorbance control or blank,

$\mathrm{A}_{\mathrm{s}}=$ absorbance with sample or standard

\section{Statistical analysis}

Data were first tested for normality and then subjected to analysis of variance (ANOVA). Significant differences between mean values were determined using Duncan's Multiple Range test $(\mathrm{P}=0.05)$ following one-way ANOVA. Partial least Squares (PLS) and principal component analysis (PCA) were used to correlate the relationships between variables by Microsoft Excel 2007-XL STAT.

\section{RESULTS AND DISCUSSION}

\section{Nutritional contents}

Nutrition contents were determined by [28] methods. The results of the nutritional content of some galactopoietics herbs are shown in table 2 . In the present study showed that carbohydrates, ash and crude fiber contents of the PA were found to be higher than other galactopoietics herbs, such as SA, MO and CP $(\mathrm{p}<0.05)$. While carbohydrates, ash and crude fiber contents of the PA were $52.18 \pm 0.02 \%, 14.26 \pm 0.01 \%$, $11.13 \pm 0.28 \%$, respectively. These results were agreed with the finding of [12] which reported carbohydrates and ash content are $53.21 \pm 0.05 \%, 7.92 \pm 0.01 \%$, respectively. According [33], an abundant amount of inorganic nutrient in plant material indicates with high ash content.

SA contained the highest average of lipid content $(6.73 \pm 0.06 \%)$ followed by PA $(5.87 \pm 0.01 \%)$, MO $(5.67 \pm 0.18 \%)$ and CP $(5.46 \pm 0.35 \%)(p<0.05)$. In these results, lipid content of SA is higher than the results obtained from [21], which reported lipid content, are ranging between $1.8-4.0 \%$. According to [34], the differences of chemical composition on the plant were influenced by geography, time of harvest, climate, etc. Lipid content demonstrated that the leaves were having dietary purposes with promising nutritional attributes.

The differences were also found in protein content, where the highest value was found in CP $(30.85 \pm 0.33 \%)$ and the lowest value in the PA (17.36 $\pm 0.18 \%$ ) (table 2 ). The result of the crude protein content of CP is same as shown by [35]. Generally, the fresh leaves of all galactopoietics herbs most contained water, e. g. Plectranthus amboinicus L. (see table 2).

Table 2 also showed that galactopoietics herbs used in Indonesia are rich sources of essential minerals, such as calcium, magnesium, zinc, potassium and iron. From the results obtained, it could be concluded that PA, SA, MO and CP are a useful edible plant, can be used as an herbal nutrition supplement.

Table 2: Comparison nutrition contents of some galactopoietics herbs used in Indonesia

\begin{tabular}{|c|c|c|c|c|c|}
\hline \multirow[t]{2}{*}{ Parameter } & \multicolumn{2}{|c|}{ Values $(\mathrm{g} / \mathbf{1 0 0 g})$} & \multirow{2}{*}{$\begin{array}{l}\text { Sauropus androgynus } \\
(\mathrm{g} / 100 \mathrm{~g})\end{array}$} & \multirow{2}{*}{$\begin{array}{l}\text { Moringa oleifera } \\
(\mathrm{g} / 100 \mathrm{~g})\end{array}$} & \multirow{2}{*}{$\begin{array}{l}\text { Carica papaya leaves } \\
(\mathrm{g} / 100 \mathrm{~g})\end{array}$} \\
\hline & Fresh & Dry & & & \\
\hline Moisture & $91.38 \pm 0.05$ & $10.33 \pm 0.04$ & $9.03 \pm 0.01$ & $9.24 \pm 0.30$ & $7.70 \pm 0.00$ \\
\hline Ash & $1.48 \pm 0.04$ & $14.26 \pm 0.01^{\mathrm{a}}$ & $9.71 \pm 0.04^{c}$ & $10.97 \pm 0.16^{\mathrm{b}}$ & $10.28 \pm 0.25^{c}$ \\
\hline Lipids & $0.60 \pm 0.03$ & $5.87 \pm 0.01^{\mathrm{bc}}$ & $6.73 \pm 0.06^{\mathrm{a}}$ & $5.67 \pm 0.18^{\mathrm{bcd}}$ & $5.46 \pm 0.35^{\mathrm{cd}}$ \\
\hline Protein & $2.02 \pm 0.08$ & $17.36 \pm 0.18^{\mathrm{d}}$ & $29.46 \pm 0.40^{\mathrm{b}}$ & $25.22 \pm 0.21^{c}$ & $30.85 \pm 0.33^{\mathrm{a}}$ \\
\hline Crude fiber & $1.09 \pm 0.11$ & $11.13 \pm 0.28^{\mathrm{a}}$ & $9.86 \pm 0.33^{c}$ & $9.34 \pm 0.28^{\mathrm{d}}$ & $10.62 \pm 0.05^{b}$ \\
\hline Carbohydrates & $1.15 \pm 0.03$ & $52.18 \pm 0.02^{\mathrm{a}}$ & $45.09 \pm 0.49^{\mathrm{cd}}$ & $48.91 \pm 0.42^{b}$ & $45.77 \pm 0.93^{\text {cd }}$ \\
\hline Energy (kcal) & $18.08 \pm 0.71$ & $330.97 \pm 1.67^{d}$ & $358.71 \pm 0.21^{\mathrm{a}}$ & $347.49 \pm 0.93^{c}$ & $355.36 \pm 0.71^{\mathrm{b}}$ \\
\hline \multicolumn{6}{|l|}{ Minerals } \\
\hline Calcium (mg/100g) & $223.5 \pm 0.71$ & & $84.40^{*}$ & $3.65^{* *}$ & $338.60^{* * *}$ \\
\hline Zinc (mg/kg) & $6.47 \pm 0.23$ & & $15.90^{*}$ & $31.03^{* *}$ & $21.40^{* * *}$ \\
\hline $\begin{array}{l}\text { Magnesium } \\
(\mathrm{mg} / 100 \mathrm{~g})\end{array}$ & $53.15 \pm 0.49$ & & $664.90^{*}$ & $0.50^{* *}$ & $439.00^{* * *}$ \\
\hline Potassium $(\mathrm{mg} / 100 \mathrm{~g})$ & $429.5 \pm 7.78$ & & $45.70^{*}$ & $1.50^{* *}$ & $676.20^{* * *}$ \\
\hline Iron (mg/kg) & $30.8 \pm 0.14$ & & $212.50^{*}$ & $490.00^{* *}$ & $32.00^{* * *}$ \\
\hline
\end{tabular}

Values are mean \pm SD. of triplicate; ${ }^{*}[21],{ }^{* *}[31],{ }^{* * *}[32], a>b>c>d$, same alphabetic in the same row $=$ no difference 


\section{Physical properties}

The results of physical properties of some galactopoietics herbs used in Indonesia were presented in table 3 . The yields of ethanolic extract of some galactopoietics herbs ranged from 0.85-2.00\% $(\mathrm{w} / \mathrm{v})$. ANOVA showed that the ethanolic extract of SA contained the highest average of yields followed by $\mathrm{CP}>\mathrm{MO}>\mathrm{PA}$ (table 3 ). These results were consistent with the finding of [16] who reported the yield of ethanolic extract of 28 Thai plants. We know that, the yield of extract plant was correlated with plant cell wall breakdown.
PA was found to have the highest $\mathrm{pH}$ value and a water activity $\left(\mathrm{a}_{\mathrm{w}}\right)$ compared to the other galactopoietics herbs $(0.00, \mathrm{p}<0.05)$. Antioxidant activity of hydroxyl-flavones in plants is influenced by $\mathrm{pH}$ [34]. $\mathrm{pH}$ value of 3-11 was required to maintain plant phytochemicals in extracts [36]. From table 3 also showed that color (L*a*b* values) from the three tested parameters, viz., $L$ (lightness), $a$ (redness), and $b$ (yellowness) for some galactopoietics herbs used in Indonesia were significantly different $(p<0.05)$. This indicated that some galactopoietics herbs were darker, greener, and less blue, except PA (less red and more yellow).

Table 3: Physical properties of some galactopoietics herbs used in Indonesia

\begin{tabular}{|c|c|c|c|c|c|c|c|c|}
\hline \multirow[t]{2}{*}{ Sample } & \multirow[t]{2}{*}{ Yields (\%) } & \multirow[t]{2}{*}{ pH } & \multirow[t]{2}{*}{$\mathbf{a}_{\mathbf{w}}$} & \multicolumn{5}{|l|}{ Color } \\
\hline & & & & $L$ & $a$ & $\boldsymbol{b}$ & hue & Preference \\
\hline $\mathrm{PA}$ & $0.85^{d}$ & $7.05 \pm 0.01^{\mathrm{a}}$ & $0.67 \pm 0.02^{\mathrm{a}}$ & $33.67^{d}$ & $4.58^{\mathrm{a}}$ & $10.81^{\mathrm{d}}$ & +0.003 & darker, less red, and more yellow \\
\hline SA & $2.00^{\mathrm{a}}$ & $6.46 \pm 0.02^{b}$ & $0.44 \pm 0.01^{\mathrm{cd}}$ & $42.06^{\mathrm{a}}$ & $-4.51^{\mathrm{cd}}$ & $23.37^{a}$ & +0.005 & darker, greener, and less blue \\
\hline MO & $0.95^{\mathrm{c}}$ & $5.74 \pm 0.02^{\mathrm{d}}$ & $0.47 \pm 0.01^{\mathrm{cd}}$ & $35.73^{\mathrm{b}}$ & $-4.81^{\mathrm{cd}}$ & $22.58^{\mathrm{b}}$ & +0.006 & darker, greener, and less blue \\
\hline $\mathrm{CP}$ & $1.25^{\mathrm{b}}$ & $6.05 \pm 0.04^{\mathrm{c}}$ & $0.51 \pm 0.01^{\mathrm{b}}$ & $34.33^{\mathrm{c}}$ & $-3.04^{b}$ & $20.88^{c}$ & +0.004 & darker, less red, and less blue \\
\hline
\end{tabular}

Values are mean \pm SD. of triplicate; $\mathrm{a}>\mathrm{b}>\mathrm{c}>\mathrm{d}$, same alphabetic in the same column = no difference; PA: Plectranthus amboinicus L., SA: Sauropus androgynus, MO: Moringa oleifera, CP: Carica papaya leaves.

\section{Total phenolics and flavonoids content}

An established method of folin-cioceltaeu reagent was used to measure the total phenolics content. The principle of this method was the reduction ability of the phenol functional group. Reduction of the phosphortungstat-phosphor molybdenum complex (folin- cioceltaeu reagent) by phenolic ions changes the reagent to dark blue [37]. The color becomes darker, as reduction ability increases with increasing phenolics compounds. The values obtained for the concentration of total phenolics content were expressed as mg gallic acid equivalent (the standard curve equation: $\mathrm{y}=0.008 \mathrm{x}-0.008, R^{2}=$ 0.998) per gram of dry weight of plant extract, mg GAE/g (table 4).

Table 4: Total phenolics content and total flavonoids of some galactopoietics herbs used in Indonesia

\begin{tabular}{llll}
\hline Sample & Total phenolics (mg GAE/g) & Total flavonoids (mg QE/g) & Ratio (TF/TP) \\
\hline Plectranthus amboinicus L. & & & \\
ethanolic extract & $49.98 \pm 0.00^{\mathrm{b}}$ & $14.49 \pm 0.00^{\mathrm{d}}$ & 0.29 \\
water extract & $53.88 \pm 0.39$ & $13.19 \pm 0.06$ & 0.09 \\
n-hexane fraction & $5.86 \pm 0.02$ & $14.19 \pm 0.09$ & 2.25 \\
ethyl acetate fraction & $8.80 \pm 0.01$ & $18.79 \pm 0.02$ & 1.61 \\
aqueous fraction & $19.53 \pm 0.01$ & $43.63 \pm 0.00^{\mathrm{a}}$ & 0.96 \\
Sauropus androgynus & $27.49 \pm 0.00^{\mathrm{d}}$ & $36.60 \pm 0.00^{\mathrm{b}}$ & 1.59 \\
Moringa oleifera & $53.89 \pm 0.39^{\mathrm{a}}$ & $21.73 \pm 0.02^{\mathrm{c}}$ & 0.68 \\
Carica papaya leaves & $47.78 \pm 0.39^{\mathrm{c}}$ & 0.45 & \\
\hline
\end{tabular}

Values are mean \pm SD. of triplicate; GAE: Gallic acid equivalent; $Q E$ : Quercetin equivalent. $a>b>c>d$, same alphabetic in the same column = no difference

Table 4 showed that the total phenolics content of some galactopoietics herbs are PA range from 5.86 to $53.88 \mathrm{mg} \mathrm{GAE} / \mathrm{g}$ of dry weight of plant extract, SA (27.59 mg GAE/g), MO (53.89 mg $\mathrm{GAE} / \mathrm{g}$ ) and CP (47.78 $\mathrm{mg} \mathrm{GAE} / \mathrm{g}$ ). As shown in the table, water extract of PA contained the highest average of total phenolics content followed by ethanolic>aqueous fraction>ethyl acetate fraction $>$ n-hexane fraction. This is because the water extract can dissolve rapidly of carbonyl and organic acids based on their polarity. Moreover, the results were agreements with [38] which reported that total phenolics content in water extract is higher than ethanol extract in Malaysia palm oil trunk epiphytes ferns.

Meanwhile, in the ethanolic extract of some galactopoietics herbs used in Indonesia, MO contained the highest average of total phenolics content followed by $\mathrm{PA}>\mathrm{CP}>\mathrm{SA}$. ANOVA analysis showed a significant of $0.000<\alpha$. It could be concluded that there was a significant difference in total phenolics content of ethanolic plant extract of some galactopoietics herbs. In these results, total phenolics content of MO is higher than the results obtained from [39], which reported range between 36-46 mg GAE/g. The obtained amount of total polyphenols in the extract indicated the extract has a high antioxidant activity [39].

Flavonoids are a natural subset of the phenolics group with antioxidant properties. Aluminum chloride colorimetric assay was used to measure total flavonoids content. The flavonoids content was expressed in terms of quercetin equivalent (the standard curve equation: $y=0.001 x+0.006, R 2=0.988), \mathrm{mg}$ of $\mathrm{QE}$ per gram of plant extract (table 4 ). Table 4 showed the amount of plant extract of some galactopoietics herbs such as PA range from 4.68 to $18.79 \mathrm{mg} \mathrm{QE} / \mathrm{g}$ of dry weight of plant extract, SA $43.63 \mathrm{mg} \mathrm{QE} / \mathrm{g}$, MO $36.60 \mathrm{mg} \mathrm{QE} / \mathrm{g}$ and CP (21.73 mg QE/g). The aqueous fraction revealed a higher total flavonoids content followed by ethanolic extract $>$ ethyl acetate fraction $>$ n-hexane fraction>water extract. According to [34], the concentration of flavonoids content in plant extract can be affected by the polarity of the solvent.

There were significant differences in total flavonoid contents among the four galactopoietics herbs, leaves extract $(p<0.05)$. The ethanolic extract of SA with a ratio of total flavonoids to total phenolics (TF/TP) was 1.59 contained the highest average of total flavonoids followed by $\mathrm{MO}>\mathrm{CA}>\mathrm{PA}$ (table 4).

In these results, the total flavonoids content of SA is higher than the results obtained from $[16,21]$, which reported total flavonoids content are $10.4 \mathrm{mg} \mathrm{RE} / \mathrm{g}$ and $15.3 \mathrm{mg} \mathrm{CE} / \mathrm{g}$, respectively. The difference concentration of total phenolics and flavonoids in plant extract depends on the several factors, such as the species, variety, harvesting time, geography, and climate or agronomy practice [40-42]. 


\section{DPPH free radical scavenging activity}

DPPH is usually used as a substrate to evaluate the antioxidant activity of antioxidants. The principle of this method is based on the reduction of the methanolic-DPPH solution in the presence of a hydrogen-donating antioxidant due to the formation of the nonradical form (DPPH-H). This reaction was indicated by the color changes of DPPH from purple to yellow. The extracts of some galactopoietics herbs showed a concentration-dependent free radical scavenging activity by inhibiting the DPPH radical and values are expressed as $\mathrm{IC}_{50} . \mathrm{IC}_{50}$ is defined as the concentration to obtain $50 \%$ of a maximum inhibition. The scavenging effect increased with increasing concentration of plant extracts. The results of an antioxidant activity (DPPH scavenging) of some galactopoietics herbs to reduce and decolorize were shown in fig. 1.

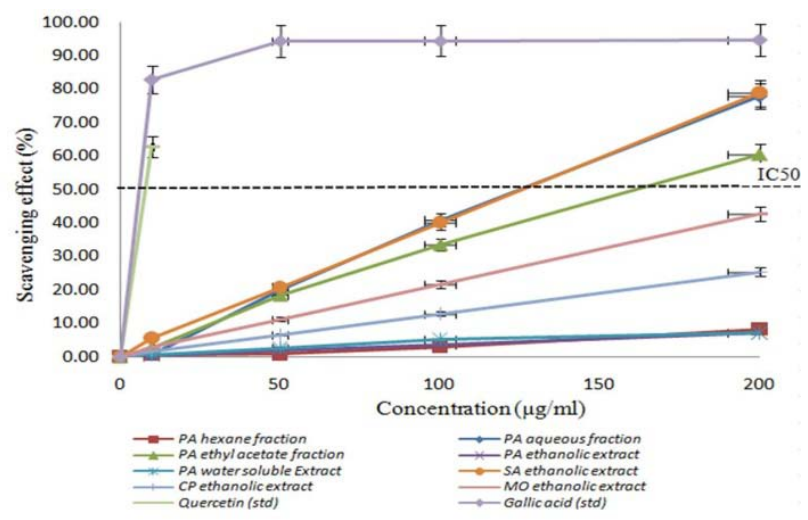

Fig. 1: An antioxidant (DPPH scavenging) activity of some galactopoietics herbs extracts on their abilities to reduce and decolorize DPPH. Data were expressed as means \pm standard deviation $(n=3)$

Antioxidant properties of plant extracts were evaluated by DPPH radical assay. A parallel to examine, the values of antioxidant activity were obtained and compared with two standard compounds, viz. gallic acid and quercetin. According to [42] reported the high scavenging effect performed on the particular sample related to the high reduction of DPPH. Fig. 1 showed that in PA, the radical scavenging activity $\left(\mathrm{IC}_{50}\right)$ was highest for an aqueous fraction $(127.77 \mu \mathrm{g} / \mathrm{ml})$, while it was least for ethanolic extract $(1428.60$ $\mu \mathrm{g} / \mathrm{ml})(\mathrm{p}<0.05)$. It could be that some target compounds of PA were purified and isolated in an aqueous fraction; meanwhile, it might be not dissolved properly in another solvent. These results agreement with [38] which showed the ethanolic extract of $\mathrm{IC}_{50}$ were lower than water extract in epiphytes fern.

Meanwhile, the radical scavenging activity ( $\mathrm{IC}_{50}$ ) of an ethanolic extract of some galactopoietics herbs showed that IC $\mathrm{C}_{50}$ of SA was highest antioxidant activity $(126.13 \mu \mathrm{g} / \mathrm{ml}$ or $239.24 \mathrm{mg} \mathrm{QE} / \mathrm{g} \mathrm{dwt})$ followed by MO $(235.76 \mu \mathrm{g} / \mathrm{ml})>\mathrm{CP}(397.62 \mu \mathrm{g} / \mathrm{ml})>\mathrm{PA}(1428.60$ $\mu \mathrm{g} / \mathrm{ml}$ ) with a significance of $0.000<\alpha$ (fig. 1 ). From these results, the antioxidant activity of ethanolic extract of SA is higher than the results obtained from [15] which reported $7.72 \pm 0.8 \mu \mathrm{mol}$ trolox/g fresh weight and lowest of IC 50 than results reported by [22] (51.08 $\mu \mathrm{g} / \mathrm{ml}$ ). SA was identified as rich sources of dietary flavonoids and antioxidant [15].

\section{Correlation of total phenolics, total flavonoids content with antioxidant activity}

The phenolics and flavonoids content can be related to the free radical scavenging activities. Phenolic compounds possess antioxidant activity that allows scavenging both active oxygen species and electrophiles, inhibiting nitrosation, and chelating metal ions [43]. The data expressed that the total phenolics and flavonoids of some galactopoietics herbs play an important role in the antioxidant activity, respectively. The results suggest that $64 \%$ of the antioxidant capacity of some galactopoietics herbs arose from the contribution of phenolic compounds and 36\% from other secondary metabolites, such carotenoids, vitamin and volatile oils, among others (table 5).

Table 5: Correlation between antioxidant activity, phenolics and flavonoids content of some galactopoietics herbs used in Indonesia

\begin{tabular}{ll}
\hline Assay & Correlation $\boldsymbol{R}^{2}$ \\
\cline { 2 - 2 } & DPPH radical scavenging ability \\
\hline Total phenolics & $0.640^{*}$ \\
Total flavonoids & $0.914^{*}$ \\
\hline
\end{tabular}

Each value in the table is represented as mean $\pm \mathrm{SD}(\mathrm{n}=3),{ }^{*}$ indicates significance at $\mathrm{P}<0.05$.

Table 5 also showed that the positive correlation between total flavonoids and antioxidant activity with regression $Y=6.657 \mathrm{x}-77.74$ $\left(R^{2}=0.914\right)$. Most of the antioxidant activity of some galactopoietics was from flavonoids compounds. The results were agreements with [16] which showed a close relationship between TPC and TFC with antioxidant of ethanolic extract of some Thai plants. Meanwhile, another researcher also reported the same correlation analysis on different plants [41-44]. The antioxidant activity of flavonoids depends on the structure and substitution pattern of hydroxyl groups [45]. However, it was difficult to attribute the antioxidant activity any of the components present in the extracts since it was a complex mixture of different chemical compounds.

Many phenolics in plants arise from the shikimic pathway, namely cinnamic, caffeic, chlorogenic and gallic acids. These are derived from phenylalanine and tyrosine, which are amino acids. The results of the regression coefficient of antioxidant activity with total phenolics content, total flavonoids content and physicochemical properties of some galactopoietics herbs to reduce and decolorize were shown in fig. 2 .

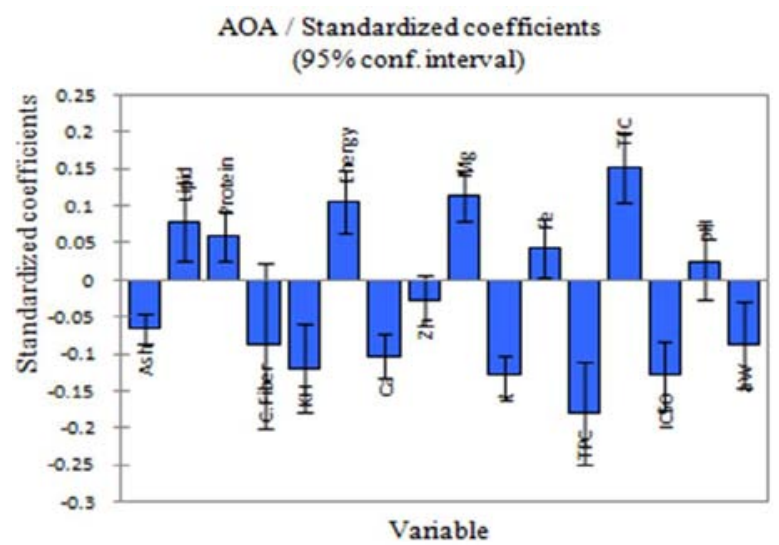

Fig. 2: The results of regression coefficient of antioxidant activity with total phenolics content, total flavonoids content, and physicochemical properties

Fig. 2 showed the correlation of antioxidant activity with total phenolics content, total flavonoids content and physicochemical properties. This illustrated the relationships between these variables for some galactopoietics herbs used in Indonesia. According to the PLS factor 1, only total flavonoids content was correlated with a positive regression coefficient with antioxidant activity (fig. 2). Since we know that flavonoids are a group of phenolic compounds, some flavonoids compounds are good antioxidant sources. Hence, it is expected that the content of the total flavonoid content relates to antioxidant activity, whereas the other chemical components did not relate to antioxidant activity. These results were also agreed with the finding of [16] who reported a good correlation between total flavonoids and antioxidant activity in some Thai plants. 


\section{Principal component analysis}

Principal component analysis (PCA) was applied to understand more about the relationship between the variables and the clustering group. According [46], to identify the most important variables or principal components (PC), the significant factor loading values higher than or equal 0.7 were used. The higher values of a variable loading, these variables have an influence in the formation of the principal component score. PCA on these attributes explained $76.6 \%$ of the variability in the data was in the first two dimensions (table 6). The first two Fs accounted for $52.4 \%$ and $24.2 \%$ of the data variance. Further components explained $22.2 \%, 0.6 \%$ and $0.4 \%$ variance, respectively. Table 6 showed that the strong positive correlation water activity $\left(\mathrm{a}_{\mathrm{w}}\right)$, crude fiber, carbohydrates and ash with the loading of F1. The loading of F2 had a strong positive correlation with calcium, potassium and antioxidant activity (IC 50 ).

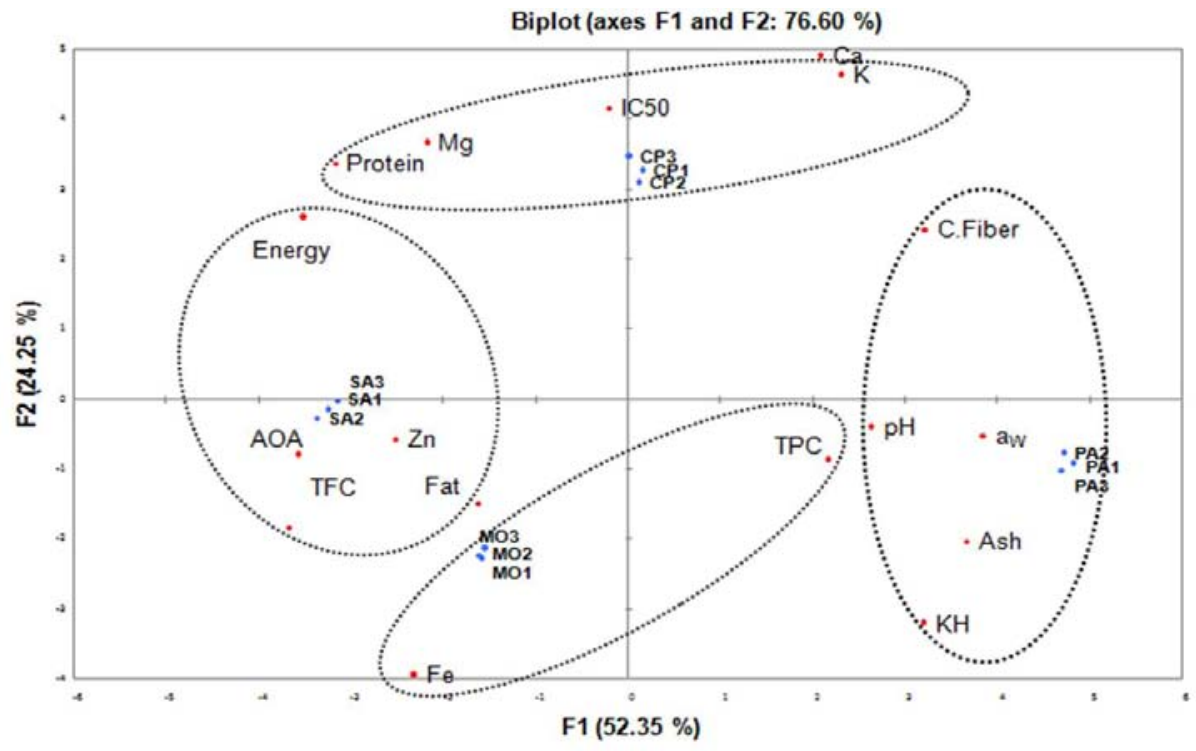

Fig. 3: Biplot obtained from PCA of variables comprising antioxidant activity, total phenolics content, total flavonoids content, and physicochemical properties

Table 6: Loading factors (Fs) of the first five principal components from principal component analysis (PCA)

\begin{tabular}{|c|c|c|c|c|c|}
\hline & F1 & F2 & F3 & F4 & F5 \\
\hline Ash & 0.930 & -0.350 & 0.060 & -0.086 & 0.020 \\
\hline Lipid & -0.414 & -0.257 & 0.836 & 0.236 & -0.087 \\
\hline Protein & -0.806 & 0.583 & -0.095 & -0.010 & -0.031 \\
\hline Crude Fiber & 0.819 & 0.421 & 0.297 & 0.146 & 0.204 \\
\hline Carbohydrates & 0.812 & -0.555 & -0.113 & 0.066 & -0.101 \\
\hline Energy & -0.890 & 0.449 & 0.031 & -0.018 & 0.014 \\
\hline $\mathrm{Ca}$ & 0.528 & 0.848 & 0.024 & 0.005 & -0.045 \\
\hline $\mathrm{Zn}$ & -0.641 & -0.097 & -0.759 & 0.064 & 0.007 \\
\hline Mg & -0.554 & 0.633 & 0.539 & -0.029 & -0.029 \\
\hline $\mathrm{K}$ & 0.585 & 0.800 & -0.126 & 0.016 & -0.043 \\
\hline $\mathrm{Fe}$ & -0.587 & -0.683 & -0.431 & 0.031 & 0.039 \\
\hline TPC & 0.549 & -0.151 & -0.820 & 0.062 & -0.008 \\
\hline TFC & -0.935 & -0.316 & 0.156 & -0.008 & 0.021 \\
\hline IC50 & -0.053 & 0.720 & -0.688 & 0.065 & -0.034 \\
\hline $\mathrm{pH}$ & 0.666 & -0.070 & 0.740 & -0.056 & 0.000 \\
\hline $\mathrm{aw}$ & 0.979 & -0.090 & 0.135 & -0.011 & -0.061 \\
\hline $\mathrm{AOA}$ & -0.909 & -0.138 & 0.391 & -0.024 & 0.012 \\
\hline
\end{tabular}

In the factor loading plots, ash was in the opposite direction to antioxidant activity and total flavonoids content were along the axis of the factor 2 (F2). Four classes were roughly grouped and used to generate the galactopoietics herbs plant image in biplots, which were combined score and loading plots (fig. 3).

Fig. 3 showed how samples of some galactopoietics herbs were differently structured according to their physicochemical composition, minerals and antioxidant properties. The first group comprised PA. According to the cluster centroid, this group presented lower values for fiber and protein, but the highest values for ash, carbohydrate, $\mathrm{pH}$, and water activity $\left(\mathrm{a}_{\mathrm{w}}\right)$. The second group comprised SA, which presented higher values for total flavonoids content and antioxidant activity. MO formed a third cluster, characterized by higher total phenolics content. Finally, a fourth group comprising CP, presented as its main characteristics, higher values of protein and lower values for carbohydrate and lipid contents.

\section{CONCLUSION}

The present study suggested that over the data set of galactopoietics herbs used in Indonesia, PLS demonstrated an accurate correlation between antioxidant activities; lipid, protein, and flavonoids content; and $\mathrm{pH}$. Only the total flavonoids content correlated strongly with antioxidant activity. Based on the PCA analysis, the data group was divided into two subsets and clustered into four groups. This provides a helpful tool for understanding much more about the interpretation of results from the experiments and the mechanism of biosynthesis in plants. Further studies are needed with these galactopoietics herbs to isolate, characterize and elucidate the 
structure of the bioactive compounds and to find out the possible mechanism of antioxidant and lactogenic activity.

\section{ACKNOWLEDGEMENT}

The authors are grateful to Ministry of Research and Technology and Higher Education, Republic of Indonesia (KEMENRISTEKDIKTI-RI) for financial assistance (03/D-SDI/PTB/X/2013) and to Bogor Agricultural University (IPB) and Indonesian Institute of Sciences (LIPI) for providing access and technical support.

\section{CONFLICT OF INTERESTS}

Declared none

\section{REFERENCES}

1. Sawa T, Nakao M, Akake T, Ono K, Maeda H. Alkylperoxyl radical-scavenging activity of various flavonoids and other phenolic compounds: implications for the anti-tumor-promoter effect of vegetables. J Agric Food Chem 1999;47:397-402.

2. World Health Organization. Global Strategy for Infant and Young Child Feeding: The Optimal Duration of Exclusive Breast Feeding. 54 th World Health Assembly. Document A54/INF. DOC./4. World Health Organization: Geneva; 2001.

3. Mannion C, Mansell D. Breastfeeding self-efficacy and the use of prescription medication: a pilot study. Obstet Gynecol Int 2012;2:562-704.

4. Walker M. Breastfeeding management for the clinician: Using the Evidence. $2^{\text {nd }}$ ed. Sudbury, MA: Jones and Bartlett Publishers; 2012.

5. Academy of Breastfeeding Medicine Protocol Committee. ABM Clinical Protocol \#9:Use of galactagogues in initiating or augmenting the rate of maternal milk secretion (first revision, January 2011). Breastfeed Med 2011;6:41-9.

6. Kim-Godwin YS. Postpartum beliefs and practices among nonWestern cultures. Am J Matern Child Nurs 2003;28:74-8.

7. Ari H, Arumingtyas EL, Indriyani S, Hakim L. Local knowledge of katuk (Sauropus androgynus (L.) Merr) in East Java, Indonesia. Int J Curr Pharm Rev Res 2016;7:210-5.

8. Damanik R, Wahlqvist ML, Wattanapenpaiboon N. Lactagogue effects of torbangun, a bataknese traditional cuisine. Asia Pac J Clin Nutr 2006;15:267-70.

9. Herawati L, Yuniati E. Ethnobotanical study of herbs of lauje ethnic communities in Tomini District, Parigi Mouton Central Sulawesi, Indonesia. Biocelebes 2014;8:26-30.

10. Mutiara K, Harijono, Estiasih T, Endang SW. Effect lactagogue moringa leaves (Moringa oleifera Lam) powder in rats white female wistar. J Basic Appl Sci Res 2013;3:430-4.

11. Mortel M, Mehta SD. A systematic review of the efficacy of herbal galactogogues. J Human Lactation 2013;29:154-62.

12. Doloksaribu TH, Syarief H, Damanik MRM, Marliyati SA. The development of torbangun flour-based functional supplementary food for breastfeeding mother. Int J Sci: Basic Appl Res 2015;1:348-55.

13. Madrano GB, Perez ML. The efficacy of malunggay (Moringa oleifera) given to near term pregnant women in including early postpartum breast milk production-a double-blind randomized clinical trial; 2015.

14. Sa'roni T, Sadjiman T, Sja'bani M, Zulaela. Effectiveness of the Sauropus androgynus (L.) Merr. leaf extract in increasing mother's milk productions. Media Litbang Kesehatan 2004;16:20-4.

15. Andarwulan N, Batari R, Sandrasari DA, Bolling B, Wijaya H. Flavonoid content and antioxidant activity of vegetables from Indonesia. Food Chem 2010;121:1231-5.

16. Maisuthisakul P, Pasuk S, Ritthiruangdej P. Relationship between antioxidant properties and chemical composition of some Thai plants. J Food Composition Anal 2008;21:229-40.

17. Damanik MRM. Torbangun: a bataknese traditional cuisine for the lactating mother in the North Sumatra Province of Indonesia. Handbook of dietary and nutritional aspects of human breast milk, Wageningen Academic Publishers; 2013. p. 1013-21.

18. Khare RS, Banerjee S, Kundu K. Coleus aromaticus benth-a nutritive medicinal plant of potential therapeutic value. Int J Pharma Bio Sci 2011;2:488-500.
19. Lukhoba CW, Simmonds MSJ, Paton AJ. Plectranthus: a review of ethanobotanical uses. J Ethanopharmcol 2006;103:1-24.

20. Kumaran, Kuranakaran RJ. Antioxidant and free radical scavenging activity of an aqueous extract of Coleus aromaticus. Food Chem 2006;97:109-14.

21. Petrus AJA. Review: Sauropus androgynus (L.) Merrill-a potentially nutritive functional leafy-vegetable. Asian J Chem 2013;25:9425-33.

22. Selvi SV, Baskar A. Evaluation of bioactive components and antioxidant activity of Sauropus androgynus plant extracts using GC-MS analysis. Int J Pharm Sci Rev Res 2012;12:65-7.

23. Sánchez-Machado DI, Núñez-Gastélum JA, Reyes-Moreno C, Ramirez-Wong B, Lopez-Cervantes J. Nutritional quality of edible parts of Moringa oleifera. Food Anal Methods 2010;3:175-80.

24. Amaglo NK, Bennet RN, Lo Curto RB, Rosa EAS, Turco VL, Giuffrida A, et al. Profiling selected phytochemicals and nutrients in different tissues of the multipurpose tree Moringa oleifera L., grown in Ghana. Food Chem 2010;122:1047-54.

25. Canini A, Alesiani D, D'Arcangelo G, Tagliatesta P. Gas chromatography-mass spectometry analysis of phenolic compounds from Carica papaya L. leaf. J Food Composition Anal 2007;20:584-90.

26. Bingna C, Hua C, Han S, Huili S, Peng W, Deke C, et al. the Lactogenic activity of an enzymatic hydrolysate from Octopus vulgaris and Carica papaya in SD rats Thai plants. J Med Food 2015;18:1262-9.

27. El-Mesallamy AMD, Hussein SAM, El-Azim MHMA, El-Gerby M. Phenolic composition and biological activities of methanolic extract of Carica papaya. Nat Prod: Indian J 2014;10:91-8.

28. Association of official analytical chemists. official methods of analysis. $15^{\text {th }}$ Ed. Association of Official Analytical Chemists. Washington, DC, USA; 1990.

29. Waterman FG, Mole S. Analysis of phenolic plant metabolites. Wiley; 1994. p. 83-8.

30. Marinova D, Ribarova F, Atanassova M. Total phenolic and total flavonoids in Bulgarian fruits and vegetables. J University Chem Technol Metallurgy 2005;40:255-60.

31. Moyo B, Julius MP, Hugo A, Voster M. Nutritional characterization of moringa (Moringa oleifera Lam.) leaves. Afr J Biotechnol 2011;10:12925-33.

32. Sharma DK, Tiwari B, Kr Singh B, Sahu S, Mathur SC, Singh RM, et al. Estimation of minerals in Carica papaya L. leaf found in Northern India by using ICP-OES technique. Int J Sci Eng Res 2013;4:1012-9.

33. Iqbal S, Younas U, Sirajuddin, Chan KW, Sarfraz RA, Uddin MK. Proximate composition and antioxidant potential of leaves from three varieties of mulberry (Morus sp.): a comparative study. Int J Mol Sci 2012;13:6651-64.

34. Maisuthisakul P. Phenolic constituents and antioxidant properties of some thai plants, phytochemicals-a global perspective of their role in nutrition and health. ed. Venketeshwer Rao; 2012.

35. Maisarah AM, Asmah R, Fauziah 0. Proximate analysis, antioxidant and antiproliferative activities of different parts of Carica papaya. J Tissue Sci Eng 2014;5:133-7.

36. Jamal JA. Malay traditional medicine, an overview of scientific and technological progress. Technical Monitor 2006;23:37-49.

37. Prior RL, Wu X, Schaich K. Standardized method for determination of antioxidant capacity and phenolics in food and dietary supplement. J Agric Food Chem 2005;53:4290-302.

38. Kormin F, Khan M, Iwansyah AC. Microwave assisted extraction; phytochemical evaluation of Malaysian palm oil trunk epiphytes ferns. Int J Pharm Pharm Sci 2016;8:1-7.

39. Sreelatha S, Padma PR. Antioxidant activity and total phenolic content of Moringa oleifera leaves in two stages of maturity. J Plant Foods Human Nutr 2009;64:303-11.

40. Srivastava MP, Tiwari R, Sharma T. Assessment of phenol and flavonoid content in the plant materials. J New Biol Reports 2013;2:163-6.

41. Saxena V, Chagti KK. The effect of climate on total phenolics in Macrotyloma uniflorum, Vigna unguiculata, Cinnamomum 
zeylanicum and Mentha piperita using spectrophotometer. Asian J Pharm Clin Res 2016;5:59-61.

42. Iwansyah AC, Mashitah MY. Physicochemical, minerals and antioxidant properties of Labisia pumila var. alata of selected geographic origins. J Agric Sci 2012;34:94-104.

43. Dai J, Mumper RJ. Plant phenolics: extraction, analysis and their antioxidant and anticancer properties. Molecules 2010;15: 7313-52.

44. Mehta V, Sharma A, Kalikhura P, Malairaman U. Antioxidant, anti-inflamatory, and antidiabetic activity of hydroalcoholic extract of Ocimum santum: an in vitro and in silico study. Asian J Pharm Clin Res 2016;5:44-9.
45. Sharififar F, Nudeh-Dehghn G, Mirtajaldini M. Major flavonoids with antioxidant activity from Teucrium polium L. Food Chem 2008;112:885-8.

46. Hair F, Anderson J, Tatham I, Black C. Multivariate data analysis. $5^{\text {th }}$ edition. New Jersey: Prentice Hall; 2005.

\section{How to cite this article}

- Ade Chandra Iwansyah, Rizal M Damanik, Lilik Kustiyah, Muhammad Hanafi. Relationship between antioxidant properties and nutritional composition of some galactopoietics herbs used in indonesia: a comparative study. Int J Pharm Pharm Sci 2016;8(12):236-243. 